\title{
CARBON-14 IN TREE RINGS IN THE VICINITY OF IGNALINA NUCLEAR POWER PLANT, LITHUANIA
}

\author{
JONAS MAZEIKA ${ }^{1}$, RIMANTAS PETROSIUS ${ }^{1}$ and RUTILE PUKIENE ${ }^{2}$ \\ ${ }^{1}$ Radioisotope Research Laboratory, Institute of Geology and Geography, \\ T. Sevcenkos 13, LT-03223 Vilnius, Lithuania \\ ${ }^{2}$ Dendroclimatology and radiometrics group, Vytautas Magnus University, \\ Z.E. Zilibero 6, LT-46324 Kaunas, Lithuania
}

Received 22 May 2007

Accepted 12 September 2007

\begin{abstract}
The results of ${ }^{14} \mathrm{C}$ measurements in the annual tree rings from the Ignalina Nuclear Power Plant (INPP) vicinity, Lithuania, for the period of its operation from 1984 to 2002 are presented. The terrestrial samples, mainly moss and related topsoil, are studied in places as well. The tree rings have shown the slightly enhanced ${ }^{14} \mathrm{C}$ activity due to operation of the nuclear power plant. The maximal calculated normalized ${ }^{14} \mathrm{C}$ release of $11 \mathrm{TBq} / \mathrm{GW}_{\mathrm{e}} / \mathrm{year}$ and the maximal effective dose of $2.0 \times 10^{-3} \mathrm{mSv} /$ year resulting from the ${ }^{14} \mathrm{C}$ were estimated for 1999 . The excess of ${ }^{14} \mathrm{C}$ specific activity measured in the moss and soil samples from moss-covered sites near the nuclear power plant (up to $0.5 \mathrm{~km}$ ) showed highly elevated ${ }^{14} \mathrm{C}$ contents (up to $813 \mathrm{pMC}$ ), probably indicating releases of the particulate material.
\end{abstract}

Keywords: Ignalina NPP, Carbon-14, Tree Rings, Airborne Release, Environment, Dose.

\section{INTRODUCTION}

${ }^{14} \mathrm{C}$ occurs naturally in the environment, due to the cosmic ray induced production in the atmosphere (Libby, 1946). At the beginning of the 19th century the concentration of ${ }^{14} \mathrm{C}$, compared to the stable isotope ${ }^{12} \mathrm{C}$, in the atmosphere began to decrease due to the increased burning of fossil fuel. In the 1950s, when many atmospheric nuclear weapon tests took place, the ${ }^{14} \mathrm{C}$ concentration in air increased sharply to a maximum (double the natural concentration), and has gradually decreased after 1960 .

${ }^{14} \mathrm{C}$ is also artificially produced in all types of nuclear reactors, including Nuclear Power Plants (NPPs) mainly through neutron-induced reactions with isotopes of carbon, nitrogen and oxygen present in the fuel, cladding, coolant, moderator and structural materials of the reactor (NCRP, 1985; IAEA, 2004). A fraction of the generated ${ }^{14} \mathrm{C}$ is released continuously during normal operation of NPPs, mainly in two chemical forms; oxidized, i.e. carbon dioxide $\left(\mathrm{CO}_{2}\right)$, and reduced, which mostly is in the form of $\mathrm{CH}_{4}$ (Levin et al., 1988). Because of the easy incorporation of ${ }^{14} \mathrm{C}$ in $\mathrm{CO}_{2}$ form into global carbon cy-

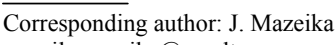

e-mail: mazeika@geo.lt cle, rapid mobility, long ${ }^{14} \mathrm{C}$ half-life and particularly considerable inventory, these releases should be considered very carefully in estimating their local and global effect on the individual effective dose and collective dose commitments. The average-normalized release rates from 1990 to 1994 are shown in $\mathrm{TBq} / \mathrm{GW}_{\mathrm{e}} /$ year in brackets for respective nuclear power reactors: CANDU (1.6) $>$ RBMK (1.3) > BWR (0.51) > PWR (0.22) (UNSCEAR, 2000).

For all types of reactors except PWRs, most of the gaseous releases of ${ }^{14} \mathrm{C}$ are in the form of ${ }^{14} \mathrm{CO}_{2}$ (IAEA, 2004), which is assimilated by plants. As a consequence, increased specific activity of ${ }^{14} \mathrm{C}$ may be found in surrounding plants and all other types of biota.

In case of the Ignalina NPP, Lithuania, the importance of ${ }^{14} \mathrm{C}$ is also due to the huge total mass of graphite per reactor, which is more than 1800 tons, and consequently large ${ }^{14} \mathrm{C}$ inventory in graphite $\left(7.0 \times 10^{14} \mathrm{~Bq}\right.$ in all the irradiated graphite constructions of a reactor) (Maceika $e t$ al., 2005).

Apart from ${ }^{14} \mathrm{C}$ in $\mathrm{CO}_{2}$ and hydrocarbons forms, the contribution of ${ }^{14} \mathrm{C}$ present in particulates from airborne release is also considered to be significant for certain types of nuclear reactors (AGRs, RBMKs) (Bush et al., 1984). 
Measurements of the ${ }^{14} \mathrm{C}$ specific activity in environmental samples are therefore useful for estimating the doses to public through terrestrial food chains. According to Lithuanian regulation, the Ignalina NPP (INPP) is required to assess doses due to releases of radionuclides during normal operation.

Since the beginning of the INPP operation, the presence of ${ }^{14} \mathrm{C}$ in the environment has been monitored in tree rings, annual and perennial aquatic and terrestrial plants, surface water and (on a smaller scale) groundwater, and other environmental samples (Mazeika, 2002). The annual terrestrial plants were investigated in greatest detail. For example, the specific activity of ${ }^{14} \mathrm{C}$ ranged from 96.2 to 123.0 pMC in Artemisia L. (1996), and from 107.1 to 178.0 pMC in alder leaves (2001). In both cases the highest specific activity of ${ }^{14} \mathrm{C}$ in Artemisia L. (123.0 pMC) and alder leaves $(178.0 \mathrm{pMC})$ were detected to the northeast of the INPP. This direction coincides with the dominant wind direction and the zone of maximum impact of releases from the NPP.

This study conducted around the INPP includes the measurements of ${ }^{14} \mathrm{C}$ in tree rings representing the period of plant operation from 1984 to 2002, and terrestrial samples, mainly moss and related topsoil. The aim of the present investigation was to study a temporal and spatial distribution of ${ }^{14} \mathrm{C}$ specific activity in environmental samples in order to indirectly derive a magnitude of annual release rate of ${ }^{14} \mathrm{C}$ and consequently to assess maximal doses for the critical group members. However ${ }^{14} \mathrm{C}$ release and dose estimates remain approximate and restrictive due to complex processes of photosynthesis and respiration (seasonal, day-night variations).

\section{SITE AND ENVIRONMENTAL SETTINGS}

The INPP is located in the northeastern part of Lithuania near the borders of Belarus and Latvia (Fig. 1).

The plant consists of two RBMK-1500 reactors.

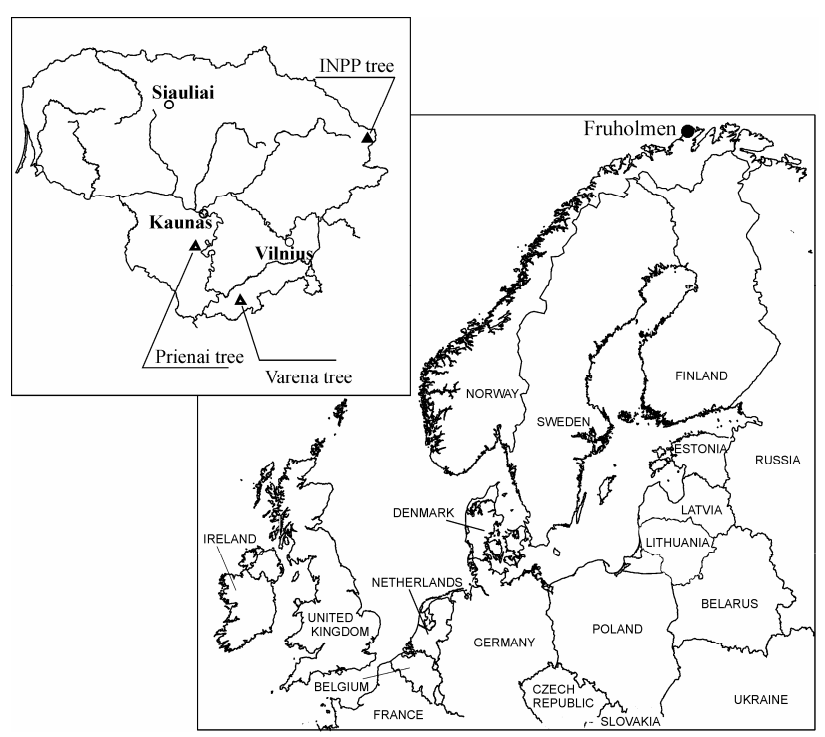

Fig. 1. Location of the trees used for a tree-ring sample preparation. Fruholmen air station - from Nydal and Lövseth (1996).
"RBMK" is a Russian acronym for "Channelled Large Power Reactor" and " 1500 " refers to the designed electrical power in units of MW. Its designed thermal rating is $4800 \mathrm{MW}$. Nominal thermal power is $4250 \mathrm{MW}$, and nominal electrical power is $1300 \mathrm{MW}$. The RBMK is a graphite-moderated boiling water channel-type reactor (Almenas et al., 1998). This means that each fuel assembly is located in separately cooled fuel channels, all surrounded by graphite. The two reactor units, Unit 1 and 2, were put into operation in December 1983 and August 1987 , respectively.

The plant uses Lake Druksiai as a natural reservoir for cooling water (Fig. 1). The surface area and volume of the lake are $4.9 \times 10^{7} \mathrm{~m}^{2}$ and $3.7 \times 10^{8} \mathrm{~m}^{3}$, respectively. The maximum depth is $33 \mathrm{~m}$ while the average depth is $7.6 \mathrm{~m}$. The Lake Druksiai is a flow-through lake with six small creeks flowing in and one river, with a water regulation dam, flowing out. The cooling water inlet and outlet channels and industrial rainwater drains are shown in Fig. 2.

The routine airborne releases are discharged via the main stacks of $150 \mathrm{~m}$ height. Releases of particles escaping during the treatment of the radioactive waste are important, too, and for certain years this pathway is much more contributing than main stacks (Nedveckaite et al., 2000). The equipment for processing of radioactive waste coming from both units is located in the western part of the industrial site and has separate ventilation systems with stacks of 75 and 12-13 m height. The dominating wind direction is from the west or southwest. About 200 000 inhabitants live within a radius of $30 \mathrm{~km}$ of the power plant. The largest cities are: Daugavpils in Latvia with the population of about $126000(30 \mathrm{~km}$ away) and Visaginas with the population of about $28800(6 \mathrm{~km}$ away). The latter is the place of residence of the INPP employees.

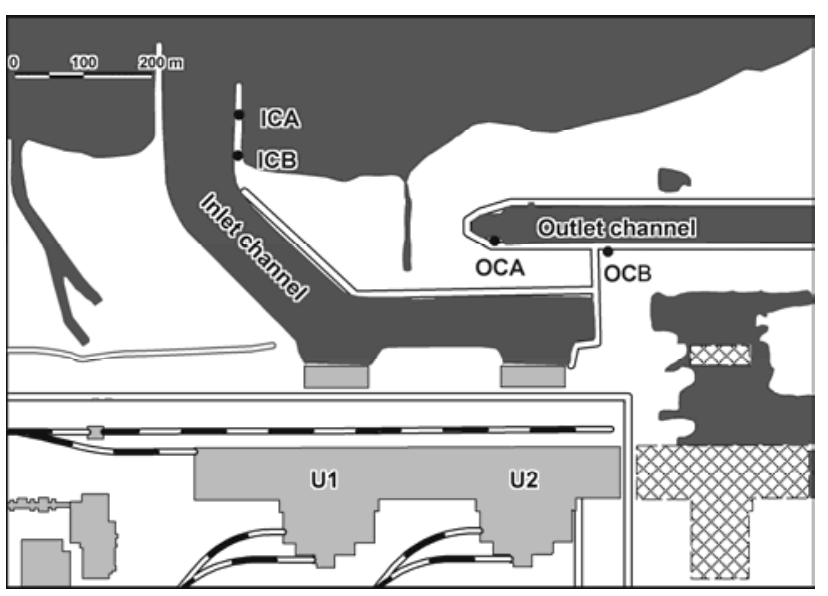

Fig. 2. Sites of collection of the moss and soil samples within the 500 $m$ area to the north from the INPP in 06.21.2005. U1 and U2 stand for Unit 1 and Unit 2. Label ICA means cooling water inlet channel, point $A$; ICB - cooling water inlet channel, point $B$; OCA - heated water outlet channel, point $A ;$ OCB - heated water outlet channel, point $B$. The pipe system from the reactor units to outlet channel is built underground. 


\section{METHODS OF INVESTIGATION}

\section{Sampling and physicochemical pre-treatment (tree, moss and topsoil)}

The samples included tree rings, as well as moss and topsoil (up to $1 \mathrm{~cm}$ ) from the layer beneath the moss vegetation collected at a short distance $(0.5-2 \mathrm{~km})$ from the power plant.

We have selected a model tree L-21 (Pinus sylvestris L.) in an area located in the vicinity of the INPP (geographical coordinates $55^{\circ} 36^{\prime} 49^{\prime \prime} \mathrm{N}$ and $26^{\circ} 34^{\prime} 53^{\prime \prime} \mathrm{E}$, elevation $156 \mathrm{~m}$ a.s.1.) in a wet Pinetum myrtillo - sphagnosum type pine forest on 07.08.2003. This area was considered as mostly affected by airborne release from the INPP. The pine stand was $60-80$ years old at this site. The model tree was 75 years old. The diameter of the trunk was $20 \mathrm{~cm}$ at the breast height. Several crosssections of the trunk of the model tree were taken for separating of annual tree rings. In order to analyse regularities of annual growth, besides the model tree ten more pine trees were sampled by an increment corer taking two cores per tree. The annual ring width fluctuations of the model tree were highly synchronous with those of other trees. Synchronic growth fluctuations indicate common growth reaction to environmental factors and characterize the model tree as a good representative of the stand.

The dependence of INPP pine tree ring width variation on climatic factors was calculated by performing correlation analysis. Meteorological data (mean monthly temperature and monthly precipitation sum) from Utena meteorological station $\left(55^{\circ} 30^{\prime} \mathrm{N}, 25^{\circ} 36^{\prime} \mathrm{E}\right)$ has been used as climatic variables. Influence of meteorological parameters of months starting from previous September to current October as well as annual temperature and precipitation was analysed (see Fig. 3). Tree ring width data was standardised calculating index chronology by ARSTAN program (Tree Ring Lab of Columbia University, USA).

The model tree L-15-95 (Pinus sylvestris L.) from the background area (Prienai) was already analysed in previous studies (Mazeika, 2002). Another model tree L-20 (Pinus sylvestris L.) was selected from a dry pine forest of Pinetum vaccinio - myrtillosum type in Varena district (geographical coordinates $54^{\circ} 02^{\prime} 30^{\prime \prime} \mathrm{N}$ and $24^{\circ} 42^{\prime} 30^{\prime \prime} \mathrm{E}$, $153 \mathrm{~m}$ a.s.l.), that is $210 \mathrm{~km}$ to the southwest from the Ignalina NPP, on 08.23.2002. The site tree stand was 100-110 years old; the model pine was 105 years old. The trunk diameter of the model tree was $38 \mathrm{~cm}$ at the breast height. In addition to the model tree, we have sampled twelve more pines by an increment corer taking two cores per tree for annual growth analysis.

Moss and topsoil sampling was carried out on 21 June 2005. The sampling locations are shown in Figs 1 and 2.

All samples were initially dried in an oven (at $45^{\circ} \mathrm{C}$ ). After drying, any foreign material was manually removed from the moss samples. The dried soil samples were sieved through a $2 \mathrm{~mm}$ mesh and any roots and plant material were manually removed. The moss samples were pyrolised (in airless conditions) to carbon without any chemical pre-treatment in order to involve bulk organics into a counting form. The annual tree rings and soil samples were oxidized with $\mathrm{MnO}_{2}$ in a reactor tube (Koval- precipitation

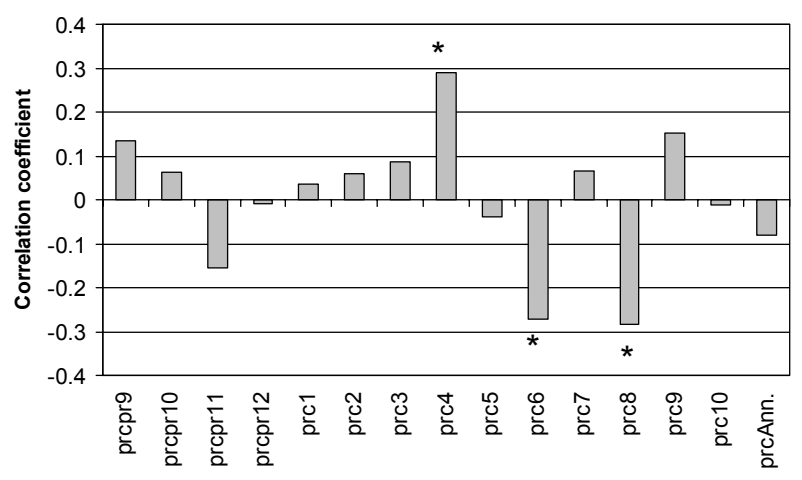

temperature

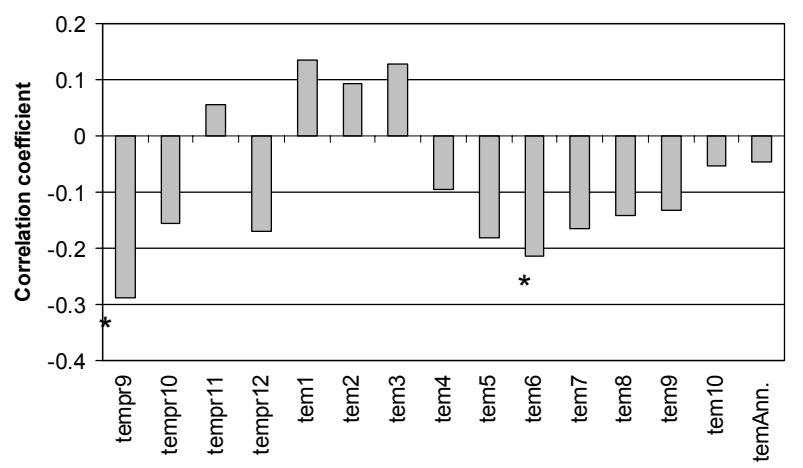

Fig. 3. Correlation between INPP pine annual growth and climatic parameters: monthly sum precipitation and mean temperature starting from previous September to current October and annual precipitation and temperature. Significant correlations are marked by asterisk.

iukh and Skripkin, 1994). Next to the carbon the oxidation of sample material with $\mathrm{MnO}_{2}$ allowed the hydrogen separation from organics and obtaining chemically bound biota water for rough measurements of ${ }^{3} \mathrm{H}$ activity in tree rings. The main stages of this pre-treatment were: 1 - drying of tree ring and soil samples at the temperature $150-200^{\circ} \mathrm{C}$ during $4-6$ hours in order to release free moisture from sample; 2 - hydrogen oxidation at the temperature $800^{\circ} \mathrm{C}$ after decomposition of cellulose to free carbon (C) and hydrogen $\left(\mathrm{H}_{2}\right) ; 3$ - condensation of $\mathrm{H}_{2} \mathrm{O}$ vapour in the trap with the liquid nitrogen; 4 - distillation $\left(\mathrm{KMnO}_{4}\right.$ was added till the full stopping of gas release, then distilled to the last drop).

\section{Analytical procedure}

The specific activity of ${ }^{14} \mathrm{C}$ in environmental samples (tree rings, moss and soil) was measured as described in (Gupta and Polach, 1985). A conventional method for synthesis of benzene was applied (Kovaliukh and Skripkin, 1994). The ${ }^{14} \mathrm{C}$ specific activity of benzene was determined by liquid scintillation spectrometry (TriCarb $3170 \mathrm{TR} / \mathrm{SL}$ ). The main performance parameters of spectrometric system for ${ }^{14} \mathrm{C}$ in benzene form with $3 \mathrm{ml}$ Teflon vials were as follows: background count rate of $0.41 \pm 0.04$ CPM; counting efficiency of $71.3 \pm 0.8 \%$; and Figure of Merit (Efficiency ${ }^{2} /$ Background) of $12380 \pm 700$. 
The ${ }^{14} \mathrm{C}$ results were presented as specific activity $(1 \mathrm{pMC}=2.26 \mathrm{~Bq} / \mathrm{kg} \mathrm{C})$. The uncertainty of results was reported at 2 and 1 sigma-level for the tree rings samples and moss (topsoil) samples respectively. The quality of the ${ }^{14} \mathrm{C}$ measurements in the Radioisotope Research Laboratory was periodically tested participating in various comparisons. The results of FIRI, organized by the University of Glasgow in 2000, indicated that most of the ${ }^{14} \mathrm{C}$ results are of standard $(3 \%)$, while a part is of high $(1.5 \%)$ precision.

The ${ }^{3} \mathrm{H}$ specific activity in biota water was additionally measured by the same liquid scintillation spectrometer using scintillation cocktail with $12 \mathrm{~mL}$ of OptiPhase "TriSafe" and $8 \mathrm{~mL}$ of water. The main performance parameters of spectrometric system for ${ }^{3} \mathrm{H}$ with $20 \mathrm{~mL}$ plastic vials were as follows: background count rate of $1.01 \pm 0.08 \mathrm{CPM}$; counting efficiency of $22.0 \pm 0.4 \%$; and Figure of Merit of $1560 \pm 120$. The normal precision of ${ }^{3} \mathrm{H}$ measurements (direct counting) in the water was recognized during the comparison, organized by the Latvian Environment Agency Laboratory (Jurmala), National Veterinarian Laboratory of Lithuania and Radioisotope Laboratory of Institute of Geology and Geography in 2004.

\section{RESULTS AND DISCUSSION}

In order to reveal the multiple influences of climatic parameters on INPP pine annual growth, we calculated the regression model of tree growth (tree-ring width) using significant climatic variables as predictors. Precipitation in April and August and mean temperatures during January to March and April to September months were found to be significant. Multiple regression coefficient $\mathrm{R}=0.63$. The set of these climatic variables explains $40.3 \%$ of tree ring width variance. The results of correlation analysis are presented in Fig. 3 and the actual and modelled tree-ring width series are shown in Fig. 4.

The results of the ${ }^{14} \mathrm{C}$ analysis in annual tree rings from the INPP area and from background regions (Prienai and Varena) together with the ${ }^{14} \mathrm{C}$ in air of the Northern Hemisphere data (Nydal and Lövseth, 1996) are pre-

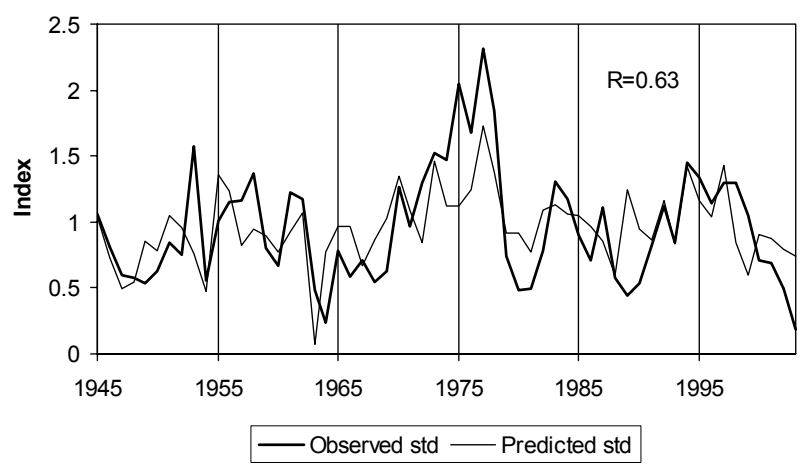

Fig. 4. Modelling of INPP pine annual growth (std - standardized chronology) using climatic predictors by a regression model $Y=3.83+0.0065 x_{1}-0.0037 x_{2}+0.0417 x_{3}-0.2073 x_{4}$, where $Y$ means modelled (predicted) index of annual growth, $x_{1}$ is April precipitation, $x_{2}-$ August precipitation, $x_{3}-$ January to March mean temperature, $x_{4}-$ April to September mean temperature. Regression coefficient $R=0.63$.

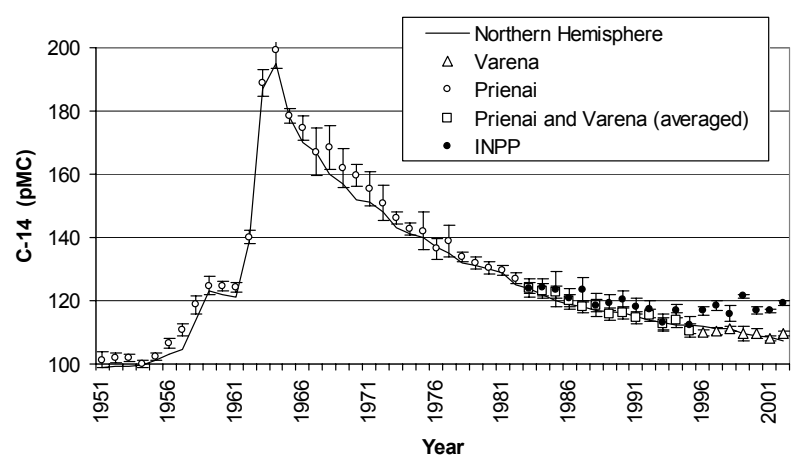

Fig. 5. The ${ }^{14} \mathrm{C}$ specific activity of pine tree rings in Lithuania, 19512002, compared with ${ }^{14} \mathrm{C}$ activity in air of Northern Hemisphere according to Nydal and Lövseth (1996).

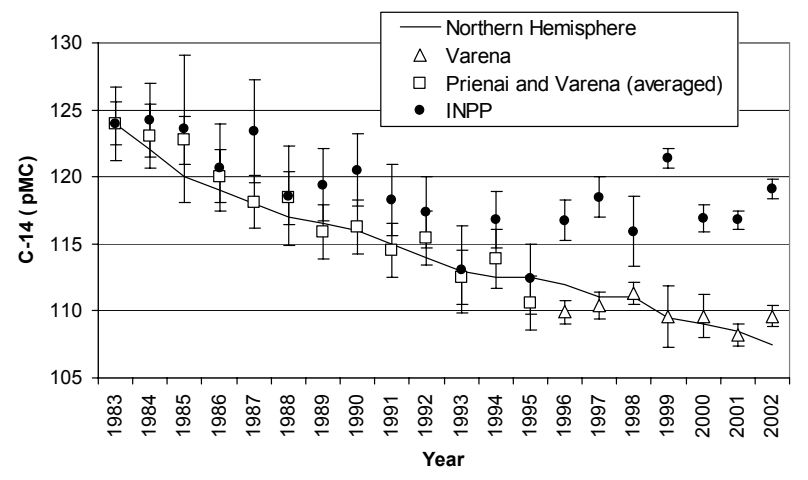

Fig. 6. The ${ }^{14} \mathrm{C}$ specific activity of pine tree rings in Lithuania for the period of INPP operation 1984-2002, compared with ${ }^{14} \mathrm{C}$ activity in air of Northern Hemisphere according to Nydal and Lövseth (1996).

sented in Figs 5 and $\mathbf{6}$.

The highest specific activity of ${ }^{14} \mathrm{C}(199.2 \mathrm{pMC})$ was determined in an annual tree ring of the Prienai tree in 1964. According to the data from the Varena tree, the specific activity of ${ }^{14} \mathrm{C}$ has been reduced with small variations in later years, and reached 109.6 pMC in 2002. In order to find out the ${ }^{14} \mathrm{C}$ excess in the annual rings of INPP tree during the operation period of 1984-2002, the mean values of specific activity of ${ }^{14} \mathrm{C}$ in the rings of Prienai and Varena trees were used as the background specific activity of ${ }^{14} \mathrm{C}$ for 1983-1995; background values were implied from the data of Varena tree, for 19962002. A comparison of the two data sets for a certain time span shows their coincidence within error limits $(2 \sigma)$ (Fig. 5). The background data of ${ }^{14} \mathrm{C}$ for the whole investigation period are in a good correlation (correlation coefficient between two data sets is 0.996 ) with the ${ }^{14} \mathrm{C}$ in air of the Northern Hemisphere (Nydal and Lövseth 1996) (Fig. 5).

A more detailed comparison of the background ${ }^{14} \mathrm{C}$ data with the ${ }^{14} \mathrm{C}$ data of the INPP tree for almost the whole operation period revealed the ${ }^{14} \mathrm{C}$ excess in tree rings (Table 1, Fig. 6). At the beginning of the INPP operation, the ${ }^{14} \mathrm{C}$ excess was negligible whereas in 19962002 , the ${ }^{14} \mathrm{C}$ excess value compared to background (Varena tree) was the highest, reaching up to 5-11 pMC. 
Table 1. The ${ }^{14} \mathrm{C}$ excess based on the tree rings measurements, respective excess air concentrations of ${ }^{14} \mathrm{C}$, calculated stack release during one year and annual doses for the INPP operation period 19842002. The electricity production data is from PRIS.

\begin{tabular}{rrrrrr}
\hline Year & $\begin{array}{c}{ }^{14} \text { C Ex } \\
\text { (pMC) }\end{array}$ & $\begin{array}{c}1^{14} \text { C CAC } \\
\text { (Bq/m })\end{array}$ & $\begin{array}{c}\text { CR/1y } \\
\text { (Bq/year) }\end{array}$ & $\begin{array}{c}\text { NRR } \\
\text { (TBq/GW } / W / \\
\text { year) }\end{array}$ & $\begin{array}{c}\text { AED } \\
\text { (mSv/year) }\end{array}$ \\
\hline 1984 & 1 & $5.5 \times 10^{-4}$ & $1.0 \times 10^{12}$ & 1.9 & $1.8 \times 10^{-4}$ \\
1985 & 1 & $5.5 \times 10^{-4}$ & $1.0 \times 10^{12}$ & 1.0 & $1.8 \times 10^{-4}$ \\
1986 & 1 & $5.5 \times 10^{-4}$ & $1.0 \times 10^{12}$ & 1.0 & $1.8 \times 10^{-4}$ \\
1987 & 5 & $2.8 \times 10^{-3}$ & $5.0 \times 10^{12}$ & 4.8 & $9.0 \times 10^{-4}$ \\
1988 & $<1$ & $<5.5 \times 10^{-4}$ & $<1.0 \times 10^{12}$ & $<0.7$ & $<1.8 \times 10^{-4}$ \\
1989 & 3 & $1.7 \times 10^{-3}$ & $3.0 \times 10^{12}$ & 1.7 & $5.4 \times 10^{-4}$ \\
1990 & 5 & $2.8 \times 10^{-3}$ & $5.0 \times 10^{12}$ & 2.8 & $9.0 \times 10^{-4}$ \\
1991 & 3 & $1.7 \times 10^{-3}$ & $3.0 \times 10^{12}$ & 1.7 & $5.4 \times 10^{-4}$ \\
1992 & 1 & $5.5 \times 10^{-4}$ & $1.0 \times 10^{12}$ & 0.7 & $1.8 \times 10^{-4}$ \\
1993 & $<1$ & $<5.5 \times 10^{-4}$ & $<1.0 \times 10^{12}$ & $<0.8$ & $<1.8 \times 10^{-4}$ \\
1994 & 3 & $1.7 \times 10^{-3}$ & $3.0 \times 10^{12}$ & 4.0 & $5.4 \times 10^{-4}$ \\
1995 & 1 & $5.5 \times 10^{-4}$ & $1.0 \times 10^{12}$ & 0.8 & $1.8 \times 10^{-4}$ \\
1996 & 7 & $3.8 \times 10^{-3}$ & $7.0 \times 10^{12}$ & 4.8 & $1.3 \times 10^{-3}$ \\
1997 & 9 & $5.0 \times 10^{-3}$ & $9.0 \times 10^{12}$ & 7.2 & $1.6 \times 10^{-3}$ \\
1998 & 5 & $2.9 \times 10^{-3}$ & $5.0 \times 10^{12}$ & 3.6 & $9.0 \times 10^{-4}$ \\
1999 & 11 & $6.1 \times 10^{-3}$ & $1.1 \times 10^{13}$ & 11.0 & $2.0 \times 10^{-3}$ \\
2000 & 7 & $3.9 \times 10^{-3}$ & $7.0 \times 10^{12}$ & 8.2 & $1.3 \times 10^{-3}$ \\
2001 & 9 & $5.0 \times 10^{-3}$ & $9.0 \times 10^{12}$ & 7.9 & $1.6 \times 10^{-3}$ \\
2002 & 9 & $5.0 \times 10^{-3}$ & $9.0 \times 10^{12}$ & 6.1 & $1.6 \times 10^{-3}$ \\
\hline
\end{tabular}

Comments: ${ }^{14} \mathrm{C}$ Ex $={ }^{14} \mathrm{C}$ Excess, ${ }^{14} \mathrm{C} \mathrm{CAC}=$ Computed air concentrations of ${ }^{14} \mathrm{C}, C R / 1 y r=$ Calculated release during one year, $N R R=$ Normalized release rate, ${ }^{14} \mathrm{C} A E D=$ Annual effective dose to adult gardeners resulting from ${ }^{14} \mathrm{C}$ airborne release.

Based on the experimentally determined values of the ${ }^{14} \mathrm{C}$ excess in the INPP tree rings, an inverse problem was analysed. The following parameters, important from the radiation and environmental protection point of view, were roughly calculated: air concentration of ${ }^{14} \mathrm{C}$, predicted by airborne releases; annually released activity of ${ }^{14} \mathrm{C}$; normalized release rate of ${ }^{14} \mathrm{C}$; and annual effective doses to critical group, resulting from ${ }^{14} \mathrm{C}$ airborne release.

The main assumptions of those calculations are based on routine release conversion factors for the farmer (gardener) exposure pathway provided in Nedveckaite et al. (2000). Following the international recommendations (IAEA, 1998), a revised INPP limitation system for atmospheric and aquatic pathway was implemented (Nedveckaite et al., 2000). In the case of atmospheric release, the nuclide specific routine release conversion factor represents the ratio of the annual effective dose for a critical group member ( $\mathrm{Sv}$ year $\left.{ }^{-1}\right)$ at the location of the highest predicted radionuclide concentration in air, to the activity released from the INPP (Bq/year). For example, the dose conversion factor for the ${ }^{14} \mathrm{C}$ released from the $150 \mathrm{~m}$ high stack was $1.8 \times 10^{-19} \mathrm{~Sv} / \mathrm{Bq}$. A radionuclide transfer factor in air representing the ratio of the annual mean air concentration $\left(\mathrm{Bq} / \mathrm{m}^{3}\right)$ to the released activity $(\mathrm{Bq} / \mathrm{s})$ was used for the estimation of the ${ }^{14} \mathrm{C}$ concentration in air. The ${ }^{14} \mathrm{C}$ transfer factor in air of $1.75 \times 10^{-8} \mathrm{~s} / \mathrm{m}^{3}$ was estimated for the maximum affected zone in the INPP environment.

The carbon dioxide $\left(\mathrm{CO}_{2}\right)$ concentration in the atmosphere has been increased by human activities from 280 ppmv at the beginning of the industrial revolution to over
370 ppmv at present (Leuenberger et al., 1992). Assuming an equilibrium between the ${ }^{14} \mathrm{CO}_{2}$ in air and ${ }^{14} \mathrm{C}$ in green plants, as well as the $\mathrm{CO}_{2}$ concentration in atmosphere equal to $330 \mathrm{ppmv}$, the ${ }^{14} \mathrm{C}$ excess in biota in terms of pMC can be linked to ${ }^{14} \mathrm{C}$ concentration in air as follows: $1 \mathrm{pMC}$ equal to $0.00055 \mathrm{~Bq} / \mathrm{m}^{3}$.

Based on the above-mentioned assumptions and the transfer factors determined in Nedveckaite et al. (2000), the main calculation results are given in Table 1.

During 1984-2002, the excess ${ }^{14} \mathrm{C}$ concentration in air ranged from $5.5 \times 10^{-4}$ to $6.1 \times 10^{-3} \mathrm{~Bq} / \mathrm{m}^{3}$, the annually released activity of ${ }^{14} \mathrm{C}$ from $10^{12}$ to $10^{13} \mathrm{~Bq}$, the normalized release rate of ${ }^{14} \mathrm{C}$ from 0.7 to $11 \mathrm{TBq} / \mathrm{GW}_{\mathrm{e}} /$ year, and the annual effective dose from $1.8 \times 10^{-4}$ to $2.0 \times 10^{-3}$ $\mathrm{mSv} /$ year respectively. The minimal indefinite values of these parameters were identified in 1988 and 1993 and the maximal values in 1999 respectively.

The release of ${ }^{14} \mathrm{C}$ based on the given estimation is the highest among the releases of other radionuclides from the INPP and resulted doses (Nedveckaite et al., 2000). Therefore, the issue of ${ }^{14} \mathrm{C}$ releases from the INPP and their distribution pattern in the environment are of great importance and requires further analysis.

The results of the ${ }^{3} \mathrm{H}$ volumetric activities in biota water of the annual tree rings from the INPP area and from background regions (Prienai and Varena) together with the ${ }^{3} \mathrm{H}$ activities in atmospheric precipitation in Lithuania are presented in Figs $\mathbf{7}$ and $\mathbf{8 .}$

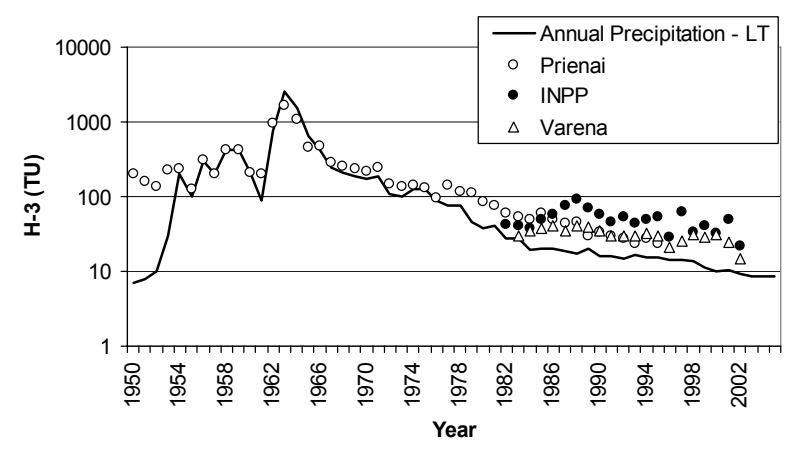

Fig. 7. The ${ }^{3} \mathrm{H}$ volumetric activity in biota water $\left(1 \mathrm{TU}=118 \mathrm{~Bq} / \mathrm{m}^{3}\right)$ from pine tree rings in Lithuania, 1951-2002, compared with ${ }^{3} \mathrm{H}$ volumetric activity in annual atmospheric precipitation in Lithuania.

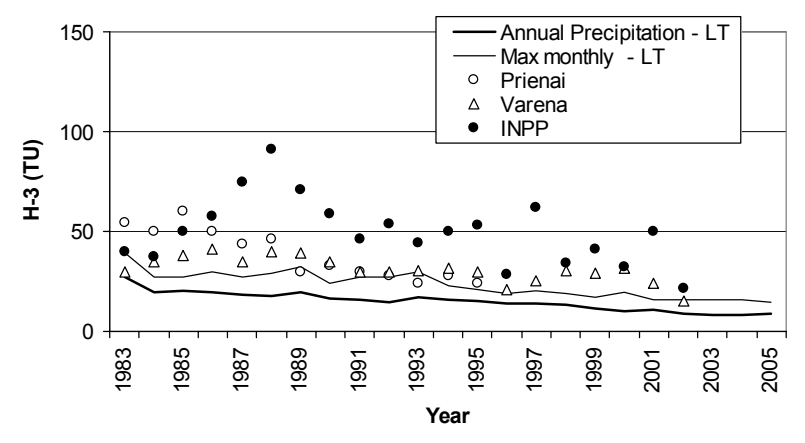

Fig. 8. The ${ }^{3} \mathrm{H}$ volumetric activity in biota water $\left(1 \mathrm{TU}=118 \mathrm{~Bq} / \mathrm{m}^{3}\right)$ from pine tree rings in Lithuania, 1983-2002, compared with ${ }^{3} \mathrm{H}$ volumetric activity in annual atmospheric precipitation and with maximum ${ }^{3} \mathrm{H}$ volumetric activity in monthly samples in Lithuania. 
Table 2. The ${ }^{14} \mathrm{C}$ specific activity in the moss and soil samples collected within $500 \mathrm{~m}$ distance from the INPP in 06.21.2005. Sampling sites are shown in Fig. 2. The contemporary background of 106.7 pMC for 2005 was measured in moss from the Vilnius district, southeastern Lithuania. The value $106.7 \mathrm{pMC}$ corresponds to volumetric activity of ${ }^{14} \mathrm{C}$ in air equal to $0.043 \mathrm{~Bq} / \mathrm{m}^{3}$ assuming that the $\mathrm{CO}_{2}$ concentration in air is 330 ppm.

\begin{tabular}{llllc}
\hline $\begin{array}{l}\text { Lab. } \\
\text { code }\end{array}$ & $\begin{array}{l}\text { Sample } \\
\text { ID }\end{array}$ & $\begin{array}{l}\text { Sample type and } \\
\text { location }\end{array}$ & \multicolumn{3}{c}{$\begin{array}{c}{ }^{14} \text { c specific } \\
\text { activity } \\
\text { (pMC } \pm 1 \sigma)\end{array}$} & $\begin{array}{c}{ }^{14} \mathrm{C} \text { excess } \\
(\mathrm{pMC} \pm 1 \sigma)\end{array}$ \\
\hline Vs-1569 BG & $\begin{array}{l}\text { Moss, the Vilnius district, } \\
\text { southeastern Lithuania }\end{array}$ & $107 \pm 2$ & \\
\hline Vs-1568 & $\begin{array}{l}\text { Moss, near the INPP } \\
\text { (1 km to the SW) }\end{array}$ & $141 \pm 2$ & $34 \pm 3$ \\
\hline Vs-1570 ICA & $\begin{array}{l}\text { Moss, inlet channel, } \\
\text { point A }\end{array}$ & $115 \pm 4$ & $8 \pm 4$ \\
\hline Vs-1571 ICB-m & $\begin{array}{l}\text { Moss, inlet channel, } \\
\text { point B }\end{array}$ & $564 \pm 7$ & $457 \pm 7$ \\
\hline Vs-1600 ICB-s & $\begin{array}{l}\text { Soil with moss remains, } \\
\text { inlet channel, point B }\end{array}$ & $813 \pm 10$ & $706 \pm 10$ \\
\hline Vs-1572 OCA-m & $\begin{array}{l}\text { Moss, outlet channel, } \\
\text { point A }\end{array}$ & $312 \pm 4$ & $205 \pm 4$ \\
\hline Vs-1567 OCB-m & $\begin{array}{l}\text { Moss, outlet channel, } \\
\text { point B }\end{array}$ & $167 \pm 2$ & $60 \pm 3$ \\
\hline Vs-1595 OCB-s & $\begin{array}{l}\text { Soil with moss remains, } \\
\text { outlet channel, point B }\end{array}$ & $203 \pm 2$ & $96 \pm 3$ \\
\hline
\end{tabular}

${ }^{3} \mathrm{H}$ data of tree rings of the same year for different locations and compared to atmospheric precipitation data showed very wide discrepancies probably related to water purification quality before counting and should be considered very carefully. However ${ }^{3} \mathrm{H}$ excess in annual tree rings of INPP area approaching to maximum value of 50 TU during the operation period of 1984-2002 could be preliminarily determined. Taking into account ${ }^{3} \mathrm{H}$ transfer factor in air $\left(1.75 \times 10^{-8} \mathrm{~s} / \mathrm{m}^{3}\right)$ and dose conversion factor for ${ }^{3} \mathrm{H}$ release from the $150 \mathrm{~m}$ high stack $\left(6.7 \times 10^{-22} \mathrm{~Sv} / \mathrm{Bq}\right.$; Nedveckaite et al., 2000) the order of magnitude of ${ }^{3} \mathrm{H}$ release from stack and resulting annual effective dose would be $10^{13} \mathrm{~Bq}$ and $10^{-5} \mathrm{mSv} /$ year respectively. These preliminary estimates are in line with data presented in Kosinsky et al., 1987.

The analysis of annual plants (tree leaves and grass) in the INPP area showed in some cases even higher ${ }^{14} \mathrm{C}$ excess than that in the tree rings. The highest concentration of ${ }^{14} \mathrm{C}$ observed in seasonal vegetation samples (tree leaves and grass) in 2001-2003 was 33 pMC higher than the contemporary background level $(106 \mathrm{pMC})$ measured in rushes (Magnuson et al., 2004). In 2001, the highest specific activity of ${ }^{14} \mathrm{C}$ in the plants of the INPP environment reached $178 \mathrm{pMC}$. After the subtraction from this value of the background value $(110 \mathrm{pMC})$, it turned out that the ${ }^{14} \mathrm{C}$ excess of about $68 \mathrm{pMC}$ in annual plants was caused by the release from the INPP (JakimaviciuteMaseliene et al., 2003). Yet unlikely the annual tree rings the annual and perennial plants may be additionally polluted with ${ }^{14} \mathrm{C}$ from a particulate material. This is especially characteristic of the moss and topsoil samples (Table 2).

The ${ }^{14} \mathrm{C}$ excess in the moss ranged from 8 to 457 pMC. The ${ }^{14} \mathrm{C}$ value in the soil samples was found to be significantly higher than in any of the vegetation samples, with the ${ }^{14} \mathrm{C}$ specific activity up to $813 \mathrm{pMC}$ (sample ID ICB-s). The highest ${ }^{14} \mathrm{C}$ excess was observed in the samples from the pier (made of large concrete blocks) of inlet channel. The ${ }^{14} \mathrm{C}$ specific activity even up to $2310 \mathrm{pMC}$ in soil samples from this pier in some places was reported in Magnuson et al. (2004). In a later study, the ${ }^{14} \mathrm{C}$ excess in the soil is derived from particulate material. Due to very uneven and rare spots with high specific activity of ${ }^{14} \mathrm{C}$ in soil, it seems unlikely that the high ${ }^{14} \mathrm{C}$ excess in the pier samples would be caused by high release rates of ${ }^{14} \mathrm{CO}_{2}$ from the main stacks in the past.

Because of the distance from the pier samples to the water level (more than $1.5 \mathrm{~m}$ ) and the medium ${ }^{14} \mathrm{C}$ content in aquatic plants (Jakimaviciute-Maseliene et al., 2003; Magnuson et al., 2004), waterborne ${ }^{14} \mathrm{C}$ releases have not been considered as a significant source of contamination. As the ${ }^{14} \mathrm{C}$ concentrations found in the moss and related topsoil samples in very limited area of the INPP environment are not diluted and extremely high, the possibility of airborne ${ }^{14} \mathrm{C}$ particulates must be considered as discussed in Mikhajlov et al. (1999), Magnuson et al. (2004).

\section{SUMMARY}

The ${ }^{14} \mathrm{C}$ concentration near the INPP has been studied by analysing annual tree rings, moss and topsoil samples using a conventional liquid scintillation spectrometry.

A comparison between the specific activity of ${ }^{14} \mathrm{C}$ in the tree rings of the INPP surroundings and specific activity of the tree rings from the background regions has revealed the ${ }^{14} \mathrm{C}$ excess for the whole operation period of the INPP (1984-2002). Based on the experimentally determined ${ }^{14} \mathrm{C}$ excess value, the maximal value of normalized release rate $\left(11 \mathrm{TBq} / \mathrm{GW}_{\mathrm{e}} /\right.$ year $)$ was calculated for the mentioned time span. In comparison with the other radionuclide releases from the INPP and respective doses, the effective dose resulting from the ${ }^{14} \mathrm{C}$ is the highest reaching $2.0 \times 10^{-3} \mathrm{mSv} /$ year.

The excess of ${ }^{14} \mathrm{C}$ specific activity measured in the moss and soil samples from moss-covered sites within short distances (up to $0.5 \mathrm{~km}$ ) from the power plant show highly elevated ${ }^{14} \mathrm{C}$ contents, probably indicating releases of the particulate material previously discussed in Magnuson et al. (2004). The ${ }^{14} \mathrm{C}$ excess farther from nuclear power plant $(30 \mathrm{~km})$ is insignificant.

\section{ACKNOWLEDGEMENTS}

This study was supported by the IAEA (LIT/9/005) and by the Lithuanian State Science and Studies Foundation under contract C-19/2003. The authors thank Mr. G. Davainis for the assistance in the laboratory and the team of Department of Climate and Water Systems at the Institute of Geology and Geography, Vilnius, for the assistance in field trips. Special thanks to two reviewers, whose comments and suggestions resulted in a significantly improved manuscript. 


\section{REFERENCES}

Almenas K, Kaliatka A and Uspuras E, 1998. Ignalina RBMK-1500, a source book. Ignalina Safety Analysis Group, Lithuanian Energy Institute: $198 \mathrm{pp}$.

Bush RP, Smith GM and Smith IF, 1984. Carbon-14 waste management. EUR 8749 EN. Luxembourg, Commission of the European Communities: 214 pp.

Gupta SH and Polach HA, 1985. Radiocarbon practices at ANU, handbook. ANU Canberra: 173 pp.

[IAEA, 1998]. Principles for limiting releases of radioactive effluents into the environment. Safety Series No. 77. International Atomic Energy Agency, Vienna, Austria: $32 \mathrm{pp}$.

[IAEA, 2004]. Management of waste containing tritium and carbon-14. Technical Report Series No.421. International Atomic Energy Agency, Vienna, Austria: 109 pp.

Jakimaviciute-Maseliene V, Mazeika J and Petrosius R, 2003. Tricio ir radioanglies pasiskirstymas Ignalinos AE rajone (Spatial distribution of tritium and radiocarbon in Ignalina NPP region). Sveikatos mokslai 3: 46-49 (in Lithuanian).

Kosinsky VV, Orlov MI and Samov VP, 1987. Obrazovaniye tritiya na AES s RBMK reaktorami i iego postupleniye $v$ okruzhayushchiuyu sredu (Production of tritium in NPP with RBMK reactors and consequent appearance into environment). Moscow: NII Atominform, $\mathrm{OH}-4-87: 20$ pp (in Russian).

Kovaliukh NN and Skripkin VV, 1994. An universal technology for oxidation of carbon-containing materials for radiocarbon dating, Abstract and papers of Conference on geochronology and dendrochronology of old town's and radiocarbon dating of archaeological findings, Lithuania, Vilnius, Oct. 31 - Nov. 4, 1994, Vilnius University Press: 37-42.

Leuenberger M, Siegenthaler U and Langway CC, 1992. Carbon isotope composition of atmospheric $\mathrm{CO}_{2}$ during the last ice age from an Antarctic ice core. Nature 357: 488-490, DOI 10.1038/357488a0.

Levin I, Kromer B, Barabas M and Münnich KO, 1988. Environmental distribution and long-term dispersion of reactor ${ }^{14} \mathrm{CO}_{2}$ around two
German nuclear power plants. Health Physics 54: 149-156

Libby WF, 1946. Atmospheric helium three and radiocarbon from cosmic radiation. Physical Review 69: 671-672, DOI 10.1103/PhysRev.69.671.2.

Maceika E, Remeikis V, Ancius D and Ridikas D, 2005. Evaluation of the radiological consequences of ${ }^{14} \mathrm{C}$ due to contaminated Ignalina NPP graphite incineration. Lithuanian Journal of Physics 45 (5): 383-391.

Magnusson Å, Stenström K, Skog G, Adliene D, Adlys G, Hellborg R, Olariu A, Zakaria M, Rääf C and Mattsson S, 2004. Levels of ${ }^{14} \mathrm{C}$ in the Terrestrial Environment in the Vicinity of Two European Nuclear Power Plants. Radiocarbon 46 (2): 863-868.

Mazeika J, 2002. Radionuclides in Geoenvironment of Lithuania. Institute of Geology, Vilnius: $216 \mathrm{pp}$.

Mikhajlov ND, Kolkovsky VM and Pavlova ID, 1999. Radiocarbon distribution in northwest Belarus near the Ignalina nuclear power plant. Radiocarbon 41(1): 75-79.

[NCRP, 1985]. Carbon-14 in the environment. National Council on Radiation Protection and Measurements. NCRP report no 81, USA: $108 \mathrm{pp}$.

Nedveckaite T, Motiejunas S, Kucinskas V, Mazeika J, Filistovic V, Jusciene D, Maceika E, Morkeliunas L and Hamby DM, 2000. Environmental releases of radioactivity and the incidence of thyroid disease at the Ignalina Nuclear Power Plant. Health Physics 79 (6): 666-674.

Nydal R and Lövseth K, 1996. Carbon-14 Measurements in Atmospheric $\mathrm{CO}_{2}$ from Northern and Southern Hemisphere Sites, 19621993. ORNL/CDIAC-93, NDP-057. Carbon Dioxide Information Center, Oak Ridge National Laboratory, Oak Ridge, Tennessee: 48 pp.

[PRIS], Power Reactor Information System, International Atomic Energy Agency. WEB site: <http://www.iaea.org/>. Accessed 2007 February 10

[UNSCEAR, 2000]. Sources and Effects of Ionizing Radiation. UNSCEAR 2000 Report to the General Assembly, with scientific annexes. United Nations Scientific Committee on the Effects of Atomic Radiation, United Nations, New York: 1215 pp. 